\title{
Efektivitas Pemberian Bubur Jawak (SETARIA ITALICA) Dalam Peningkatan Berat Badan dan Tinggi Badan Pada Balita Stunting di Kecamatan Kayan Hilir Kabupaten Sintang
}

\section{THE EFFECTIVENESS OF GIVING BUBUR JAWAK (SETARIA ITALICA) IN THE INCREASING WEIGHT AND HEIGHT OF BODY IN STUNTING CHILDREN IN KECAMATAN KAYAN HILIR, SINTANG}

\author{
Paskalia Tri Kurniati ${ }^{*}$, Sunarti $^{2}$ \\ ${ }^{1}$ Program Studi Kebidanan, STIKES Kapuas Raya Sintang, Kalimantan Barat, \\ Indonesia \\ ${ }^{2}$ Program Studi Kebidanan, STIKES Kapuas Raya Sintang, Kalimantan Barat, \\ Indonesia \\ *Korespondensi penulis: liakurniati14@gmail.com
}

Penyerahan: 18-09-2020, Perbaikan: 07-12-2020, Diterima: 08-12-2020

\begin{abstract}
Stunting is a toddler with nutritional status based on length or height according to the age. According the WHO standard, the Z-score is less than -2SD is categorized as stunting (Ministry of Health, 2020). The study aimed to determine the effectiveness of giving bubur jawak (Setaria Italica) in increasing body weight and height in stunting toddler in the Lalang Inggar village and Nyangkom village, Kayan Hilir District, Sintang Regancy. This study was a quasi-experimental one-group pre-test - post-test design. A total of 45 samples with total sampling, namely all stunting toddler in Lalang Inggar and Nyangkom in the Kayan Hilir district, Sintang regancy. Data analysis used paired t-test with normal data distribution. The results of the study showed that there was an increase in body weight $(p<0.005)$ and height $(p<0.001)$ toddler in stunting in the Kayan Hilir district, Sintang Regancy. The provision of Bubur jawak (Setaria Italica) is effective in increasing body weight and height for the toddler in stunting in the Kayan Hilir District, Sintang. It is suggested to utilize local food including consumption of processed jawak seeds to improve the nutrional status of toddlers.
\end{abstract}

Keywords: Stunting, Jawak Porridge

\begin{abstract}
ABSTRAK
Stunting adalah balita dengan status gizi berdasarkan panjang atau tinggi badan menurut umur. Dengan standar baku WHO, jika nilai Z-scorenya kurang dari -2SD maka dikategorikan pendek dan dikategorikan sangat pendek jika nilai Z-scorenya kurang dari 3SD (Kemenkes, 2020). Tujuan penelitian untuk mengetahuai efektivitas pemberian bubur jawak (setaria italica) dalam peningkatan berat badan dan tinggi badan pada balita stunting di Kecamatan Kayan Hilir Kabupaten Sintang. Metode Penelitian yang digunakan pada penelitian ini menggunakan rancangan quasi - experimental one group pre test post test design. Sebanyak 45 sampel dengan total sampling yaitu seluruh balita stunting di Desa Lalang Inggar dan Desa Nyangkom, Kecamatan Kayan Hilir Kabupaten Sintang. Analisis data menggunakan paired t test dengan sebaran data normal. Hasil penelitin menunjukkan terdapat peningkatan berat badan $(p<0,005)$ dan tinggi badan $(p<0,001)$ pada balita stunting di Kecamatan Kayan Hilir Kabupaten Sintang. Pemberian bubur jawak (setaria italica) efektif dalam peningkatan berat badan dan tinggi badan pada balita stunting di Kecamatan Kayan Hilir Kabupaten Sintang. Disarankan dapat memanfaatkan pangan lokal termasuk konsumsi olahan biji jawak untuk meningkatkan status gizi balita.
\end{abstract}

Kata kunci: Stunting, bubur jawak 


\section{PENDAHULUAN}

Program prioritas pembangunan kesehatan periode tahun 2015-2019 difokuskan pada penurunan angka kematian ibu dan bayi, pengendalian penyakit menular dan pegendalian penyakit tidak menular dan penurunan prevalensi balita pendek (Kemenkes, 2016). Balita pendek (Stunting) adalah balita dengan status gizi berdasarkan panjang atau tinggi badan menurut umur. Menurut standar WHO, jika nilai z-score kurang dari-2SD maka termasuk kedalam kategori pendek dan jika kurang dari -3SD maka termasuk kategori sangat pendek (Kemenkes, 2020). Stunting dapat meningkatkan resiko kematian anak, mempengaruhi pengembangan motorik dan kognitif, mempengaruhi tingkat kecerdasan di sekolah, dan mengurangi produktivitas di usia anak ketika dewasa (Black, 2013). Stunting pada anak balita merupakan salah satu faktor penghambat bagi pembangunan manusia (UNICEF, 2012).

Secara global tahun 2017 sebanyak $22,2 \%$ atau sekitar 150,8 juta balita di dunia mengalami stunting, angka ini sudah mengalami penurunan di tahun 2018 yaitu $21,9 \%$ (149 juta balita), dan terus menurun di tahun 2019 yaitu 21,3\% (144 juta balita). Lebih dari setengah balita stunting di dunia berasal dari Asia (54\%) sedangkan lebih dari sepertiganya (40\%) tinggal di Afrika. Dari 83,6 juta balita stunting di Asia, proporsi terbanyak berasal dari Asia Selatan $(31,7 \%)$ dan proporsi paling sedikit di Asia Timur (4,5\%) (WHO, 2020).

Hasil Studi Status Gizi Balita Indonesia (SSGBI) tahun 2019 menunjukkan angka prevalensi balita stunting pada tahun 2013 adalah $37,2 \%$, turun sebesar $6,4 \%$ di tahun 2018 yaitu $(30,8 \%)$ dan terus turun 3,1 persen di tahun 2019 yaitu $27,67 \%$. Prevalensi balita gizi kurang pada 2019 berada di angka $16,29 \%$. Sementara itu untuk prevalensi balita wasting (kurus), berada pada angka 7,44 dan angka ini mengalami penurunan yaitu 2,76 \% (Rakernas Kemenkes, 2020). Masih tinggi nya prevalensi stunting di Indonesia sebesar 27,67\% menunjukkan bahwa prevalensi stunting masih di atas $20 \%$, artinya belum mencapai target WHO yang di bawah 20\% (Kemenkes, 2020).

Prevalensi balita stunting di Kalimantan Barat tahun 2017 yaitu $36,5 \%$ (Sangat pendek $13 \%$ dan pendek 23,50\%). Angka ini turun di tahun 2018 yaitu 33,3\% (sangat pendek 11,40 dan pendek 21,90) (Kemenkes RI, 2018). Hasil Utama Riskesdas 2018 Provinsi Kalimantan Barat menunjukkan angka prevalensi stunting di Kabupaten Sintang tahun 2013 adalah 47,7\% dan menurun di tahun 2018 yaitu 33,15 (sangat pendek 24,27\% dan Pendek 8,88\%) (Kemenkes RI. 2018). Angka prevalensi stunting di Desa Lalang Inggar sebanyak 32 balita $(66,67 \%)$ sedangkan desa Nyangkom sebanyak 13 balita $(32,5 \%)$, dimana kedua desa ini yang merupakan desa dengan lokasi kasus stunting tertinggi di Kecamatan Kayan Hilir (Dinkes Kab. Sintang, 2018)

Penelitian sebelumnya dilakukan

oleh Tirajoh (2015) tentang Pemanfaatan Jawawut (Setaria italica) Asal Papua sebagai Bahan Pakan Pengganti Jagung. Hasil penelitian menunjukkan Evaluasi nilai nutrisi menunjukkan jawawut asal Papua (Setaria italica) berpotensi dijadikan sebagai bahan pakan sumber energi dengan kandungan bahan kering 88,37\%; karbohidrat sebesar $83,99 \%$; protein 12,07\%; lemak 2,76\%; serat kasar 1,93\%; energi metabolis $3.139 \mathrm{kkal} / \mathrm{kg}$; $\mathrm{Ca} 1,25 \%$ dan $\mathrm{P0}, 18 \%$ (Tirajoh, $\mathrm{S}$. 
2015). Selain itu terdapat penelitian sejenis tentang Jewawut dengan judul Penambahan Gembili Pada Flakes Jewawut Ikan Gabus Sebagai Alternatif Makanan Tambahan Anak Gizi Kurang. Penelitian ini menunjukkan Jewawut Ikan Gabus dapat digunakan Sebagai alternatif makanan tambahan bagi anak gizi kurang. Takaran jumlah sajian yang disarankan untuk flakes Jewawut Ikan Gabus dengan penambahan tepung gembili $10 \%$ dari $125 \mathrm{~g}$ per sajian (Gisca, B. 2013). Tujuan penelitian untuk mengetahuai efektivitas pemberian bubur jawak (setaria italica) dalam peningkatan berat badan dan tinggi badan pada balita stunting di Kecamatan Kayan Hilir Kabupaten Sintang.

\section{METODE}

Jenis penelitian ini adalah penelitian dengan pendekatan kuantitatif dengan desain penelitian ini adalah Quasi Experimental. Desain penelitian yang akan digunakan adalah dengan pendekatan Pre Eksperimen, perencanaan yang digunakan adalah One Group Pre test dan Post Test. Serta menggunakan teknik total sampling.

Sampel merupakan seluruh balita stunting di Desa Lalang Inggar dan Desa Nyangkom yang diberikan makanan tambahan bubur jawak (setaria italica) sebanyak $100 \mathrm{gr}$ setiap pagi hari sebagai menu sarapan yang diberikan selama tiga bulan. Jumlah sampel sebanyak 45 balita. Tehnik sampling menggunakan total sampling yaitu seluruh populasi balita stunting akan dijadikan sampel dalam penelitian.
Penelitian akan dilaksanakan di Kecamatan Nanga Mau Kabupaten Sintang pada bulan April-Juni 2020. Data yang dikumpulkan meliputi karakteristik keluarga, karakteristik balita, riwayat ASI Eksklusif, antropometri ibu dan balita. Data sekunder meliputi keadaan umum lokasi penelitian. Pengumpulan data primer dilakukan dua kali periode yaitu sebelum pemberian bubur jawak (Pre), dan setelah intervensi atau setelah pemberian makanan tambahan bubur jawak (Post). Penelitian ini sudah lolos kaji etik dari Komisi Etik Penelitian Kesehatan STIKIM.

\section{HASIL}

\section{Karakteristik Responden}

Berdasarkan tabel 1 diketahui dari 45 responden yang diteliti didapatkan hasil sebagian responden yang memiliki umur $0-12$ bulan sebanyak 8 responden $(17,8 \%)$, responden yang berumur $13-36$ bulan yaitu 20 responden $(44,4 \%)$ dan responden yang berumur 37-60 bulan yaitu sebanyak 17 responden $(37,8 \%)$.Berdasarkan jenis kelamin menunjukkan sebagian besar responden memiliki jenis kelamin perempuan yaitu sebanyak 29 responden $(64,4 \%)$ dan sebagian kecil memiliki jenis kelamin laki-laki yaitu 16 responden (35,6\%). Berdasarkan pendapatan keluarga menunjukkan sebagian besar keluarga responden memiliki pendapatan rendah yaitu 28 responden $(62,2 \%)$ dan sebagian kecil memiliki pendapatan tinggi yaitu 13 responden $(28,9 \%)$. 
Tabel 1. Karakteristik Responden

\begin{tabular}{lcc}
\hline Karakteristilk & $\mathbf{n = 4 5}$ & $\mathbf{\%}$ \\
\hline Umur & & \\
$0-12$ bulan & 8 & 17,8 \\
$13-36$ bulan & 20 & 44,4 \\
$37-60$ bulan & 17 & 37,8 \\
Jenis Kelamin & 16 & 35,6 \\
$\quad$ Laki-laki & 29 & 64,4 \\
$\quad$ Perempuan & & \\
Pendapatan Keluarga & 28 & 62,2 \\
$\quad$ Rendah (< Rp.2. 461.000) & 17 & 37,8 \\
$\quad$ Tinggi ( $\geq$ Rp.2. 461.000) & & \\
Pendidikan ibu & 32 & 71,1 \\
$\quad$ Pendidikan Rendah & 32,9 \\
$\quad$ Pendidikan Tinggi & 13 & 28 \\
Total & 45 & 100 \\
\hline
\end{tabular}

\section{Analisis Univariat}

Berdasarkan tabel 2 menunjukkan bahwa berat badan balita sebelum pemberian intervensi ( $p r e$ test) bubur jawak dengan berat badan 5,0-6,9 kg sebanyak 10 responden $(22,2 \%)$, $7,0-8,9 \mathrm{~kg}$ sebanyak 9 responden (20\%), 9,0-10,9 kg sebanyak 14 responden $(31,1 \%)$ dan responden yang memiliki berat badan $11,0-12,9$ kg sebanyak 12 responden $(26,7 \%)$.
Berdasarkan

tabel

menunjukkan bahwa berat badan balita setelah pemberian intervensi (post test) bubur jawak dengan berat badan 5,0-6,9 $\mathrm{kg}$ sebanyak 10 responden $(22,2 \%), \quad 7,0-8,9 \mathrm{~kg}$ sebanyak 8 responden $(17,8 \%), 9,0-$ $10,9 \mathrm{~kg}$ sebanyak 15 responden $(33,3 \%)$ dan responden yang memiliki berat badan 11,0-12,9 kg sebanyak 12 responden $(26,7 \%)$.

Tabel 2. Berat Badan Balita Pre dan Post Test

\begin{tabular}{ccccc}
\hline Berat Badan & $\mathbf{n = 4 5}$ & $\mathbf{\%}$ & $\mathbf{n = 4 5}$ & $\mathbf{\%}$ \\
\hline $5,0-6,9 \mathrm{~kg}$ & 10 & 22,2 & 10 & 22,2 \\
$7,0-8,9 \mathrm{~kg}$ & 9 & 20,0 & 8 & 17,8 \\
$9,0-10,9 \mathrm{~kg}$ & 14 & 31,1 & 15 & 33,3 \\
$11,0-12,9 \mathrm{~kg}$ & 12 & 26,7 & 12 & 26,7 \\
\hline Total & 45 & 100,0 & 45 & 100,0 \\
\hline
\end{tabular}

Tabel 3. Tinggi Badan Balita Pre dan Post Test

\begin{tabular}{ccccc}
\hline Tinggi Badan & $\mathbf{n = 4 5}$ & $\mathbf{\%}$ & $\mathbf{n = 4 5}$ & \% \\
\hline $50-59 \mathrm{~cm}$ & 3 & 6,7 & 3 & 6,7 \\
$60-69 \mathrm{~cm}$ & 5 & 11,1 & 5 & 11,1 \\
$70-79 \mathrm{~cm}$ & 7 & 15,6 & 7 & 15,6 \\
$80-89 \mathrm{~cm}$ & 18 & 40,0 & 15 & 33,3 \\
$90-99 \mathrm{~cm}$ & 12 & 26,7 & 15 & 33,3 \\
\hline Total & 45 & 100,0 & 45 & 100,0 \\
\hline
\end{tabular}

Berdasarkan tabel 3 menunjukkan bahwa tinggi badan balita sebelum pemberian intervensi (pre test) bubur jawak dengan tinggi badan $50-59 \mathrm{~cm}$ sebanyak 3 responden $(6,7 \%), 60-69$ $\mathrm{kg}$ sebanyak 5 responden $(11,1 \%)$, $70-70,9 \mathrm{~cm}$ sebanyak 7 responden $(15,6 \%), 80-89 \mathrm{~cm}$ sebanyak 18 responden $(40 \%)$ dan responden yang memiliki tinggi badan 90-99,9 cm sebanyak 12 responden $(26,7 \%)$. Kemudian berdasarkan tabel 3 diketahui bahwa tinggi badan balita setelah pemberian intervensi (post test) bubur jawak dengan tinggi badan 50-59 cm sebanyak 3 responden $(6,7 \%), \quad 60-69 \mathrm{~kg}$ sebanyak 5 responden $(11,1 \%), 70-$ $70,9 \mathrm{~cm}$ sebanyak 7 responden $(15,6 \%), 80-89 \mathrm{~cm}$ sebanyak 15 
responden $(33,3 \%)$ dan responden yang memiliki tinggi badan 90-99,9 $\mathrm{cm}$ sebanyak 15 responden (33,3\%).

Tabel 4 Efektivitas Pemberian Bubur Jawak (Setaria Italica) Dalam Peningkatan Berat Badan

\begin{tabular}{lcccc}
\hline \multicolumn{1}{c}{ Berat Badan } & $\mathbf{n = 4 5}$ & Mean & SD & P value \\
\hline $\begin{array}{l}\text { Sebelum diberikan intervensi } \\
\text { bubur jawak }\end{array}$ & 45 & 8,882 & 2,1573 & 0,001 \\
$\begin{array}{l}\text { Sesudah diberikan intervensi } \\
\text { bubur jawak }\end{array}$ & 45 & 9,038 & 2,1309 & \\
\hline
\end{tabular}

Tabel 5 Efektivitas Pemberian Bubur Jawak (Setaria Italica) Dalam Peningkatan Tinggi Badan

\begin{tabular}{lcccc}
\hline \multicolumn{1}{c}{ Tinggi Badan } & $\mathbf{n = 4 5}$ & Mean & SD & P value \\
\hline $\begin{array}{l}\text { Sebelum diberikan intervensi } \\
\text { bubur jawak }\end{array}$ & 45 & 81,356 & 10,6625 & 0,005 \\
$\begin{array}{l}\text { Sesudah diberikan intervensi } \\
\text { bubur jawak }\end{array}$ & 45 & 81,753 & 10,9802 & \\
\hline
\end{tabular}

\section{Analisis Bivariat}

Berdasarkan tabel 4 efektivitas pemberian bubur jawak (setaria italica) dalam peningkatan berat badan pada balita stunting di Kecamatan Kayan Hilir Kabupaten Sintang diketahui bahwa pemberian bubur jawak dapat meningkatkan berat badan responden rata-rata 8,882 (sebelum dilakukan intervensi pemberian bubur jawak) berubah naik menjadi 9,038 (sesudah dilakukan intervensi pemberian bubur jawak). Hasil uji Paired Sampel T-Test diperoleh $\mathrm{p}$ value $=0,001$ artinya secara statistik pemberian bubur jawak efektif meningkatkan berat badan balita stunting di Kecamatan Kayan Hilir Kabupaten Sintang.

Berdasarkan tabel 5 efektivitas pemberian bubur jawak (setaria italica) dalam peningkatan tinggi badan pada balita stunting di Kecamatan Kayan Hilir Kabupaten Sintang diketahui bahwa pemberian bubur jawak dapat meningkatkan tinggi badan rata-rata 81,356 (sebelum dilakukan intervensi pemberian bubur jawak) berubah naik menjadi 81,753 (sesudah dilakukan intervensi pemberian bubur jawak). Hasil uji Paired Sampel T-Test diperoleh $p$ value $=0,001$ artinya secara statistik pemberian bubur jawak efektif meningkatkan tinggi badan balita stunting di Kecamatan Kayan Hilir Kabupaten Sintang.

\section{PEMBAHASAN \\ Efektivitas Pemberian Bubur Jawak (Setaria Italica) Dalam Peningkatan Berat Badan Balita Stunting di Kecamatan Kayan Hilir Kabupaten Sintang}

Berdasarkan hasil penelitian pemberian bubur jawak (setaria italica) dalam peningkatan berat badan pada balita stunting di Kecamatan Kayan Hilir Kabupaten Sintang diketahui bahwa pemberian bubur jawak dapat meningkatkan berat badan responden rata-rata 8,882 (sebelum dilakukan intervensi pemberian bubur jawak) berubah naik menjadi 9,038 (sesudah dilakukan intervensi pemberian bubur jawak). Hasil uji Paired Sampel $T$-Test diperoleh $\mathrm{p}$ value $=$ 0,001 artinya secara statistik pemberian bubur jawak efektif meningkatkan berat badan balita stunting di Kecamatan Kayan Hilir Kabupaten Sintang.

Hasil penelitian ini sejalan dengan penelitian yang dilakukan Giotama Demando, dkk (2019) dengan judul Potensi Tanaman Jejawut Sebagai Sumber Karbohidrat 
Terbarukan dan Bioaktivitasnya Sebagai Anti Hipertensi, dimana hasil dalam penelitian ini bahwa karbohidrat yang terkandung dalam jewawut lebih tinggi dibanding gandum, yang mana jewawut berpotensi sebagai sumber pangan fungsional, terutama sebagai sumber energi. Hal ini juga sejalan dengan penelitian sebelumnya yang dilakukan oleh Rahmat Hidayat, dkk (2015) dengan judul Pengaruh Pemberian Biji-bijian Bebas Pilih Terhadap Konsumsi Pakan dan Bobot Badan Burung Kenari (Serinus Canaria) dimana hasil terjadi pertambahan bobot badan 0,03 g/ekor/hari pada burung kenari.

Pertumbuhan fisik sering dijadikan sebagai indikator dalam pengukuran status gizi baik individu mapun kelompok untuk mengetahui keadaan gizi mereka. Pertumbuhan fisik dapat berupa pertumbuhan anak, yang merupakan ukuran antropometri yang digunakan. Berat badan dapat digunakan untuk melihat laju pertumbuhan fisik. Hal ini dapat juga dilihat dari pemberian makanan tambahan. Jawak adalah salah satu dari sekian banyak sumber pangan alternatif pengganti nasi atau sumber karbohidrat dengan nama ilmiah (setaria Italica). Bijik jawak memiliki kandungan bahan kering 88,37\%; karbohidrat sebesar $83,99 \%$; protein $12,07 \%$; lemak 2,76\%; serat kasar 1,93\%; energi metabolis $3.139 \mathrm{kkal} / \mathrm{kg} ; \mathrm{Ca} 1,25 \%$ dan P0,18\%.

Hasil penelitian ini diketahui bahwa sebagian besar terjadi adanya peningkatan berat badan pada balita stunting setelah pemberian bubur jawak yang dikonsumsi sebagai menu sarapan pagi setiap harinya selama tiga bulan. Pemanfaatan biji jawak yang merupakan pangan lokal sebagai alternatif makanan tambahan perlu terus diberikan, karena merupakan alternatif pengganti nasi dengan sumber karbohidrat yang baik bagi tubuh sehingga diharapkan semakin sering balita diberikan makanan olahan biji jawak akan memberikan dampak pada pertumbuhan balita yaitu peningkatan berat badan balita. Namun hal ini juga perlu didukung oleh asupan gizi lainnya yang di konsumsi oleh balita seperti mengkonsumsi telur, ikan, sayur dan buah-buahan.

Efektivitas Pemberian Bubur Jawak (Setaria Italica) Dalam Peningkatan Tinggi Badan Balita Stunting di Kecamatan Kayan Hilir Kabupaten Sintang

Berdasarkan hasil penelitian efektivitas pemberian bubur jawak (setaria italica) dalam peningkatan tinggi badan pada balita stunting di Kecamatan Kayan Hilir Kabupaten Sintang diketahui bahwa pemberian bubur jawak dapat meningkatkan tinggi badan rata-rata 81,356 (sebelum dilakukan intervensi pemberian bubur jawak) berubah naik menjadi 81,753 (sesudah dilakukan intervensi pemberian bubur jawak). Hasil uji Paired Sampel T-Test diperoleh $\mathrm{p}$ value $=0,001$ artinya secara statistik pemberian bubur jawak efektif meningkatkan tinggi badan balita stunting di Kecamatan Kayan Hilir Kabupaten Sintang.

Hasil penelitian ini sejalan dengan penelitian sebelumnya yang dilakukan oleh Rika Junita Purba (2018) yang berjudul Pengaruh Pendidikan Gizi dan Pemberian Makanan Tambahan Nugget Ikan Tamban terhadap Peningkatan BB dan TB pada Siswa Kelas 1 SD yang Mengalami Stunting di Desa Pantai Labu yang mana didapatkan hasil bahwa ada pengaruh signifikan $p<0,05$ terhadap peningkatan berat badan dan tinggi badan setelah pendidikan gizi dan pemberian makanan tambahan berbahan ikan 
tamban, dimana hasil sebelum diberi PMT nugget ikan tamban memiliki tinggi badan rata-rata $107,59 \mathrm{~cm}$ dan setelah pemberian rata-rata menjadi $108,71 \mathrm{~cm}$.

Tinggi badan adalah jarak dari puncak kepala hingga telapak kaki. Parameter ini merupakan parameter yang menggambarkan keadaan pertumbuhan skeletal dan tidak sensitif untuk mendeteksi permasalahan gizi pada waktu yang singkat. Parameter tinggi badan mempunyai banyak kegunaan, salah satunya dalam penilaian status gizi (Sugianto, 2015). Status gizi termasuk tinggi badan balita merupakan salah satu indikator ditentukan oleh Asupan zat gizi baik makro ataupun mikro (Kemenkes, 2016). Asupan zat gizi dapat diperoleh dari beberapa zat gizi, diantaranya yaitu zat gizi makro seperti energi karbohidrat, protein dan lemak. Zat gizi makro merupakan zat gizi yang dibutuhkan dalam jumlah besar oleh tubuh dan sebagian besar berperan dalam penyediaan energi pada balita. Jawak adalah salah satu dari sekian banyak sumber pangan alternatif pengganti nasi atau sumber karbohidrat dengan nama ilmiah (Setaria Italica). Dalam bahasa Inggris dikenal dengan nama Foxtail Millet, karena memang bentuk tangkainya menyerupai ekor rubah. Bijik jawak memiliki kandungan gizi lengkap yang diperlukan oleh tubuh untuk pertumbuhan. Kandungan gizi biji jawak antara lain bahan kering 88,37\%; karbohidrat sebesar $83,99 \%$; protein $12,07 \%$; lemak 2,76\%; serat kasar 1,93\%; energi metabolis $3.139 \mathrm{kkal} / \mathrm{kg}$; Ca1,25\% dan P0,18\% (Tirajoh, S. 2015).

Hasil penelitian ini diketahui adanya peningkatan tinggi badan pada balita stunting setelah pemberian bubur jawak yang dikonsumsi dalam menu sarapan pagi. Hal ini tidak terlepas dari asupan gizi lainnya yang juga dikonsumsi oleh balita stunting. Namun tidak semua balita mengalami peningkatan tinggi badan. Hal ini disebabkan oleh makanan tambahan lainnya yang tidak sama jenisnya dikonsumsi oleh balita stunting. Selain itu keterbatasan ekonomi masyarakat, akses ke pelayanan kesehatan menjadi faktor lain terjadinya stunting. Oleh sebab itu arahan untuk terus-menerus secara berkelanjutan mengkonsumsi bubur jawak sebagai menu tambahan diterapkan dalam pemenuhan nutrisi sehari-hari. Besarnya kandungan karbohidrat, protein, dan lemak yang terkandung dalam bijik jawak ini berpotensi sekali dalam peningkatan kesehatan tubuh yaitu tinggi badan.

\section{SIMPULAN}

Diketahui dari 45 responden yang diberikan intervensi pemberian bubur jawak sehingga dapat disimpulkan bahwa pemberian bubur jawak efektif meningkatkan berat badan dan tinggi badan balita stunting di Kecamatan Kayan Hilir Kabupaten Sintang.

\section{SARAN}

Berdasarkan hasil penelitian dan simpulan, disarankan bagi tenaga kesehatan khususnya petugas gizi dan bidan hendaknya dapat meningkatkan pengetahuan ibu balita tentang gizi tepat untuk balita dan dapat berkoordinasi dengan kader serta tokoh masyarakat untuk dapat menggalakkan pemanfaatan pangan lokal termasuk konsumsi olahan biji jawak untuk meningkatkan status gizi balita.

\section{DAFTAR PUSTAKA}

Black RE, Victoria CG, Walker SP, Bhutta ZA, Christian P, de Onis $M$ et al. 2013. Maternal and Child undernutrition and overweight in low-income and 
middle-income countries. Lancet. DOI:10.1016/SO1406736(13)60937-x

Dinas Kesehatan Kabupaten Sintang. 2018. Profil Dinas Kesehatan Kabupaten Sintang 2018. Bidang KIA Dinas Kesehatan Kabupaten Sintang.

Gisca, B. 2013. Penambahan Gembili Pada Flakes Jewawut Ikan Gabus Sebagai Alternatif Makanan Tambahan Anak Gizi Kurang. Program Studi IImu Gizi Fakultas Kedokteran Universitas Diponegoro. Journal of Nutrition College, Volume 2, Nomor 4, Tahun 2013, Halaman 505-513. Online di : http://ejournals1.undip.ac.id/index.php/jnc.

Kementrian Kesehatan RI. 2016. Situasi balita pendek. Pusat data dan informasi. Jakarta. (serial online) diakses 7 Maret 2020 jam 08.30. URL : http://www.depkes.go.id/resour ces/download/pusdatin/infodati $\mathrm{n} /$ situasi-balita-pendek 2016.pdf.

2018. Hasil Utama Riskesdas 2018 Kementerian Kesehatan Badan Penelitian Dan Pengembangan Kesehatan Provinsi Kalimantan Barat. Badan Penelitian dan Pengembangan Kesehatan Kementerian RI tahun 2018. https://dinkes.kalbarprov.go.i d/wpcontent/uploads/2019/03/Hasi I-Utama-RISKESDAS-2018.pdf 2018. Riset Kesehatan Dasar (Riskesdas). Badan Penelitian dan Pengembangan Kesehatan Kementerian RI tahun 2018. http://www.depkes.go.id/reso urces/download/infoterkini/ma teri_rakorpop_2018/Hasil\%20 Riskesdas\%202018.pdf. Diakses Agustus 2020.
1. 2019. Infografis Studi Status Gizi Balita Indonesia. https://www.litbang.kemkes.g o.id/infografis-studi-statusgizi-balita-indonesia/ 2020. Keputusan Menteri Kesehatan RI nomor : 2 Tahun 2020 Tentang Standar Antropometri Anak : Direktorat Jendral Bina Gizi dan Kesehatan Ibu dan Anak. http://hukor.kemkes.go.id/upl oads/produk_hukum/PMK_No_ _2_Th_2020_ttg_Standar_Ant ropometri_Anak.pdf

2020. Studi Kasus Gizi Balita Terintegrasi Susenas 2019. https://www.kemkes.go.id/res ources/download/info-

terkini/Rakerkesnas-2020/02-

Side

event/SE_08/Studi\%20Status \%20Gizi\%20Balita\%20Terinte grasi\%20SUSENAS\%20 2019\%20(Kapus\%20Litbang\% 20UKM).pdf

Sugianto, O.S.C. 2015. Perbandingan Tinggi Badan dan Rentang Tangan Pada Anak Balita Usia 1-5 tahun. Jurnal Kedokteran Diponegoro.

https://www.neliti.com/id/publ ications/109847/perbandingan -tinggi-badan-dan-rentangtangan-pada-anak-balita-usia1-5-tahun

Sugiyono. 2015. Metode Penelitian Pendidikan Pendekatan Kuantitatif, Kualitatif, Dan $R \& D$. Bandung ; Alfabeta. (serial online) diakses tanggal 23 juni 2020. URL : http://juke.kedokteran.unila.a c.id/index.php/medula/article/ view/2179

Tirajoh, S. 2015. Pemanfaatan Jawawut (Setaria italica) Asal Papua sebagai Bahan Pakan Pengganti Jagung. Balai Pengkajian Teknologi Pertanian Papua, Jl. Yahim No.49, 
Sentani,Jayapura. siskatirajoh2006@yahoo.com. WARTAZOAVol. 25 No. 3 Th. 2015 HIm. 117-124 DOI: http://dx.doi.org/10.14334/wa rtazoa.v25i3.1156

UNICEF Indonesia Laporan Tahunanan 2012. (Serial Online) Diakses 10 November 2016.

https://www.unicef.org/indone sia/id/UNICEFAnnualReport(In d) 130731.pdf.

World Health Organization. 2013. Childhood Stunting: Challenges and opportunities. Department of Nutrition for Health and Development World Health Organization Avenue Appia 20, CH-1211 Geneva 27, Switzerland. 2013. Fax: +41 $227914156 \quad$ Email: nutrition@who.int www.who.int/nutrition.

2020. Joint child malnutrition estimates (UNICEF-WHO-WB). Geneva: World Health Organization.https://www.who .int/data/gho/data/themes/top ics/joint-child-malnutritionestimates-unicef-who-wb 